\title{
O Aleksandr Niévski de Sergei Eisenstein (por trás do fotograma)
}

\author{
Noé Silva
}

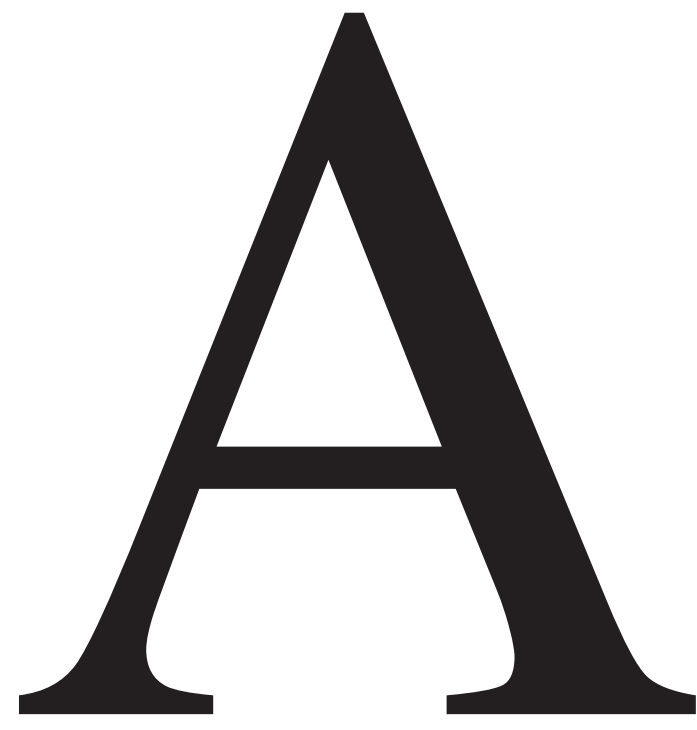

leksandr Niévski, talvez a mais popular personagem da história russa, entrou para os fastos como guerreiro, diplomata e santo, e a homônima película tornou-o mundialmente conhecido.

A primeira versão do roteiro, publicada em fins de 1937, suscitou enormes expectativas da imprensa e da academia, motivando um simpósio de historiadores no estúdio Mosfilm, em abril do ano seguinte. Criticaram-se muitas passagens do texto e liberdades em relação à plausibilidade histórica, mas, à iminência de mais uma grande guerra no continente, podia 
perfeitamente relativizar-se a fidedignidade. Aleksandr Niévski fez-se com os dados não vetados pelos censores do Partido Comunista, e não como uma crônica histórica, mas como filme de arte, embora com grande carga de propaganda, já que cumpria uma determinada tarefa política. Concluído em tempo relativamente curto (cinco meses), ele constitui a mais famosa obra clássica do cinema da URSS e uma das primeiras experiências de explorar um tema do passado medieval russo para atender a uma encomenda governamental.

O realizador Mikhail Romm relata um seu encontro com Sergei Eisenstein, em que este lhe perguntara que roteiro teria escolhido entre Mínin e Pojárskii, de Víktor Chklóvskii, e Aleksandr Niévski, de Piotr Pavliénko'. Romm respondeu que teria ficado com o primeiro, por um motivo muito simples: afinal, tratava-se do século XVII, havia registro dos acontecimentos e, entre muitas coisas, sabia-se, por exemplo, até como as pessoas se vestiam, ao passo que não se conhecia quase nada da época da segunda personagem. "Por isso mesmo", disse Eisenstein, "é que eu devo pegar o Aleksandr Niévski. Do jeito que eu fizer, assim ficará a ser!”2. E, efetivamente, muito da hodierna imagem do príncipe, de patriota fervoroso e defensor da Rússia, pode creditar-se a Eisenstein.

1 Víktor Boríssovitch Chklóvskii (1893-1984) e Piotr Andriéevitch Pavliénko (1899-1951) são escritores soviéticos.

2 Naum Kleiman, "Aleksandr Niévski", entrevista à revista eletrônica Eto-fake.livejournal (disponível em: http:// eto-fake.livejournal.com/1005511.html). Kozmá Mínin (1562-1616), oriundo da classe dos mercadores, e Dmítrii Pojárskii (1578-1641), nobre e militar profissional, encabeçaram a luta contra os invasores polacos (1610).
Para além de inventividade e audácia, seja dito, teve ele, também, sangue-frio e muita autoconfiança. O seu perdido Biéjin lug $(O$ Prado de Biéjin, 1935) não agradara a Stálin, e teria havido uma ordem de prisão contra ele, firmada por Kaganóvitch e Vorochílov e só não concretizada pela falta da assinatura de Mólotov³ ${ }^{3}$ Estava-se em uma época de terror para os cidadãos soviéticos, em particular os intelectuais, cientistas e membros da indústria cinematográfica, e esse período de intimidação política deve ter feito Eisenstein imaginar as consequências de um novo malogro para a sua vida - entre 1938 e 1939, seriam presas (e, provavelmente, executadas logo depois) pessoas muito ligadas a ele, como o escritor Isaac Bábel, que o ajudara a revisar a referida película, o diretor teatral Vsiévolod Meierkhold e o poeta Sergei Tretiakov. O êxito da empreitada trar-lhe-ia de volta o prestígio e colocá-lo-ia em sítio seguro no campo ideológico ${ }^{4}$.

Para além de muitos outros auxiliares competentes e devotados, com ele estava trabalhando gente igualmente talentosa: o letão Evguiénii Tisse (1897-1961), operador de câmera, e o compositor Sergei Prokófiev (1891-1953). Este ora levava um trecho

3 Lázar Moissiéevitch Kaganóvitch (1893-1991): dirigente do PCUS e homem de confiança de Stálin, que não tomava nenhuma decisão difícil sem consultá-lo. É considerado o idealizador do culto à personalidade do tirano. Kliment Efriémovitch Vorochílov (18811969): ministro da Defesa (1934-1940); personalidade medíocre, só atingiu altos postos por Stálin haver exterminado os generais mais capazes das forças armadas, o que contribuiu para a facilidade do avanço dos nazistas até $15 \mathrm{~km}$ de Moscou. Viatcheslav Mikháilovitch Mólotov (1890-1986): ministro das Relações Exteriores (1937-1949).

4 O pretexto para as perseguições políticas e expurgos foi o assassínio, provavelmente a mando de Stálin, de Serguiéi Mirónovitch Kírov (1886-1934), dirigente do Partido em Leningrado. 


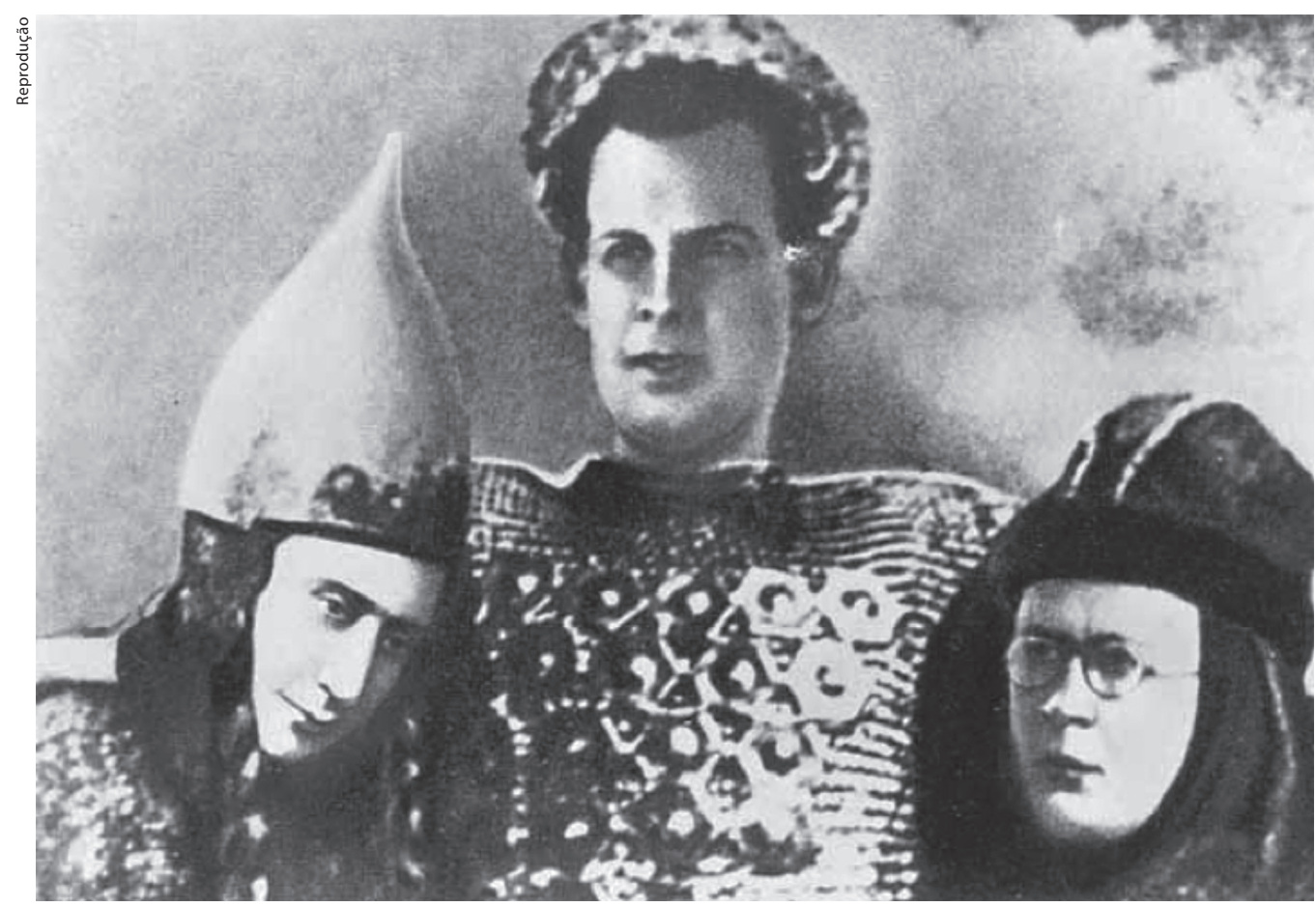

Tisse, Eisenstein e Prokófiev (de óculos) em trajes e armaduras do século XIII

musical pronto a Eisenstein, que, com base nele, fazia alguns bosquejos, ora recebia uma passagem do filme, junto com algumas indicações do realizador, para compor a música correspondente ${ }^{5}$.

Estudiosos afirmam que os contemporâneos não exageravam em dizer que a contribuição do roteirista Piotr Pavliénko para o bom êxito de Aleksandr Niévski também fora significativa. O primeiro encontro dele com Eisenstein foi em Perediélkino, vila de datchas (casas de campo) de escritores e intelectuais a $40 \mathrm{~km}$ de Moscou; Pavliénko

5 Acerca da colaboração Eisenstein-Prokófiev, ver: Douglas W. Gallez, "The Prokofiev-Eisenstein Collaboration: 'Nevsky' and 'Ivan' Revisited", in Cinema Journal, vol. 17, n. 2, University of Texas Press, Spring, 1978, pp. 13-35 (disponível em: jstor.org); Russell Merrit, "Recharging 'Aleksandr Nevsky': Tracking the Eisenstein-Prokofiev War Horse", in Film Quaterly, vol. 48, n. 2, University of California Press, Winter, 1994-1995, pp. 34-47 (disponível em: jstor.org). apresentou-lhe o roteiro, intitulado Rus, de 23 páginas datilografadas, em que o cineasta rabiscou observações apenas pontuais. Em abril, os dois percorreram juntos as cidades e locais da ação da história (Nóvgorod, Pskov, Lago Tchudskóie e Vladímir) e, com as impressões colhidas in loco, alteraram o texto, que quase triplicou de extensão. Ambos ficaram satisfeitos com o trabalho conjunto: "Piotr Andriéevitch agradou-me imensamente como escritor e pessoa. [...] Eu gostaria que todos os meus colegas escritores tivessem a oportunidade de trabalhar com Sergei Mikháilovitch"6.

6 R. A. Sokolov, "Piervonatchálnyi stsenárii P. A. Pavliénko k kinofil'mu 'Aleksandr Niévski'" ("O roteiro inicial de P. A. Pavliénko para o filme 'Aleksandr Niévski'"), in Izviéstiia Samarskovo naútchnovo tsentra Rossíiskoi akadiémii nauk (Boletim do Centro Científico da Academia Russa das Ciências, filial de Samara), vol. 17, n. 3-2, 2015, pp. 503-6. 


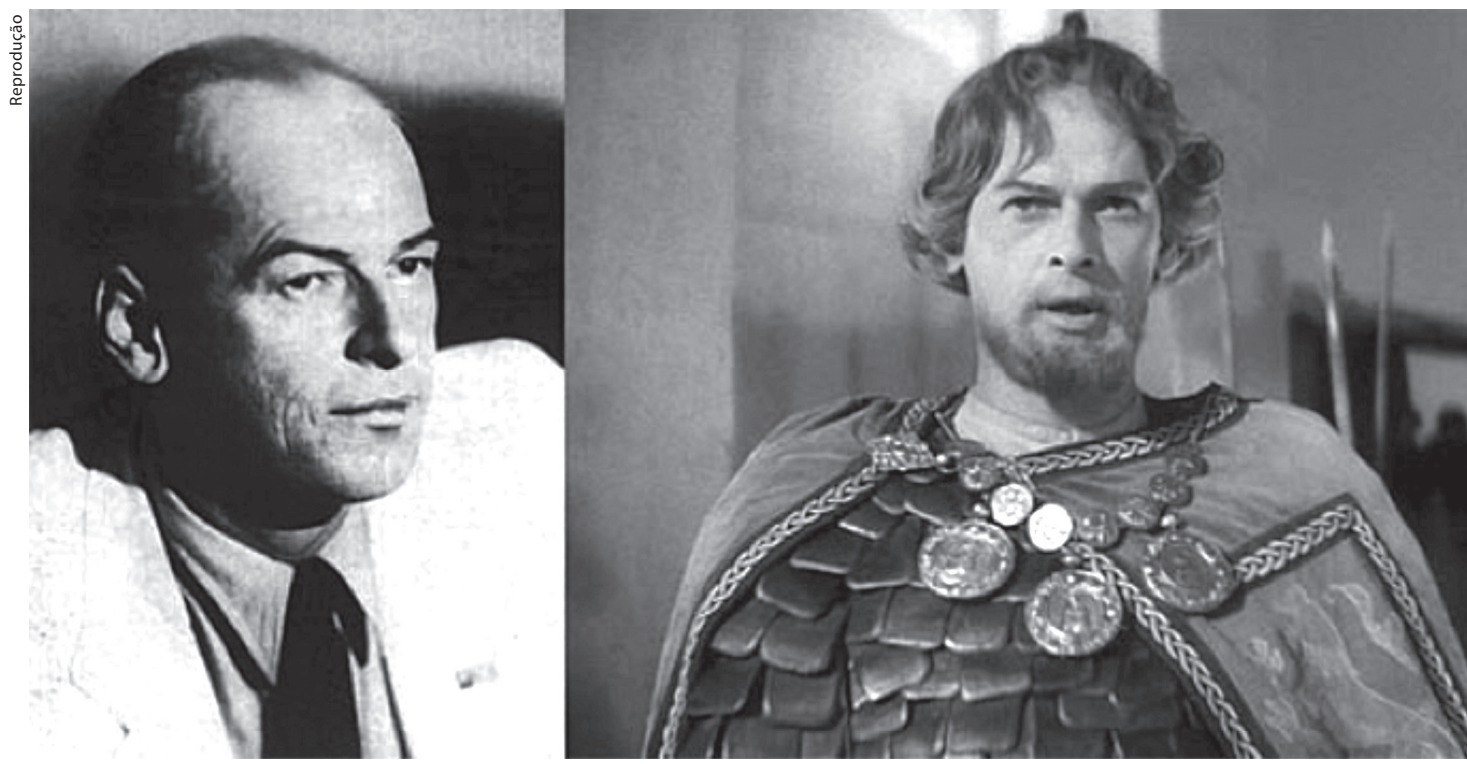

Nikolai Tcherkássov à época e o seu príncipe Niévski

E não se esqueçam os atores, especialmente Nikolai Tcherkássov (1903-1966). Ele começara em 1919, num estúdio de mímica, e participara, seis anos depois, num trio de palhaços, formado por um imitador de Carlitos (Charlie Chaplin), um magricela alto e narigudo ("Pat", ele) e um baixote gordo ("Patachón"); à época, era já aluno do Instituto de Artes Cênicas (1923-1927) de Leningrado, sua cidade natal, e atuava no teatro. Trabalhara no cinema mudo, com os filmes Vossa Excelência (Vache Prevoskhodítelstvo) e O poeta e o tsar (Poet $i$ tsar), ambos de 1927. A fama chegara-lhe com Os filhos do capitão Grant (Diéti kapitana Granta, 1935) e Deputado do Báltico (Deputat Báltiki, 1936, o seu papel preferido, de um total de 48), baseado na vida e obra de Kliment Timiriázev (18431920), físico e naturalista. E, em 1937, um ano antes do convite de Eisenstein, interpretara Aleksiéi, filho de Pedro, o Grande, em Pedro I (Piotr Piérvyi). Assim, antes de encarnar o príncipe Niévski, ele tinha já os seus bons créditos firmados e era um artista muito popular.

Ao talento de Tcherkássov e à sua experiência em representar personagens históricas associavam-se caracaterísticas físicas convenientes à figura retratada, como altura, boa compleição e voz de bom timbre. Os cabelos escuros, as rugas e a adiantada calva de um quase quarentão necessitado de parecer um rapaz loiro de 22 anos não constituíram trabalho para os maquiadores e barbeiros, supervisionados por Eisenstein; este examinava o ator de vários ângulos, acompanhado do responsável pelas vestimentas, para mudar uma coisa ou outra na sua armadura de guerreiro ${ }^{7}$.

O filme é tão bem feito, que a ilusão de realidade é total e esquecemos estar diante

7 Os artistas podem parecer um pouco velhos para os seus papéis, mas à época, ainda início do cinema falado, havia poucos atores. Ademais, a expectativa de vida, na Idade Média, devia ser baixa, de forma que Niévski poderia perfeitamente parecer mais velho. 
de artistas nos seus papéis. E Tcherkássov não precisa dizer a quem representa; desde o berro aquietador dos mongóis e o chape-chape das suas largas passadas na parte rasa do Lago Plechtchéevo, no início do filme, ele confere à personagem um ar senhoril e uma firmeza de atitudes e palavras que a colocam imediatamente acima de todas as demais (a sua atuação valeu-lhe um convite para o papel principal da obra seguinte do diretor, Ivan, o Terrível, 1939). Com a música de Prokófiev e as famosas palavras "Kto $s$ metchóm $k$ nam pridiot, tot ot metchá i poguíbnet" ("Quem com uma espada a nós vier, duma espada morrerá"), de autoria de Pavliénko, o seu Aleksandr Niévski gravou-se na memória de cada russo.

Ele continuaria ligado à personagem. No verão de 1942, copiando a Ordem do Santo e Fiel Príncipe Aleksandr Iaroslávovitch, instituída pela imperatriz Catarina, a Grande, no século XVIII, e existente até o ano de 1917, o governo soviético criaria a Ordem de Aleksandr Niévski, a mais alta condecoração militar russa, com o perfil do ator cunhado na medalha. Ele faleceu no dia 14 de setembro de 1966 e foi enterrado no território do mosteiro de Aleksandr Niévski (São Petersburgo), em cuja Catedral da Trindade se encontram os restos mortais do príncipe.

\section{$* * *$}

No dia 5 de julho de 1938, o grupo do estúdio Mosfilm e o elenco iniciaram os trabalhos em Pereslavl-Zaliéskii (400 $\mathrm{km}$ a nordeste de Moscou), onde vivera Aleksandr Iaroslávovitch, após as suas disputas com os boiardos de Nóvgorod e onde ele receberia os embaixadores, que viriam chamá-lo de volta. Num local onde tudo transpirava história, Eisenstein e Tcherkássov deambularam, várias vezes, pela cidade e arredores e escalaram muralhas e campanários, a imaginarem o que poderia haver-se aberto aos olhos e aos pensamentos das pessoas de então.

Findas as filmagens, em meados de novembro, Eisenstein, já de volta à capital, entregou-se à montagem e, quando dava mais uma demão à trilha sonora (eram os primórdios do cinema falado), teve, por ordem do Krémlin, que exigia a entrega da película, de dar o trabalho por concluído. A organização haver-se-ia satisfeito com algo que cumprisse a tarefa, temporária, de nos dois ou cinco anos antes da guerra e, quem sabe, até algum tempo após ela, fazer os cidadãos orgulharem-se da sua terra e prepararem-se para defendê-la, mas o realizador, dentro dos limites a ele impostos, pusera no fotograma o que vira, sentira e quisera expressar e, com tal, produzira uma obra para a história do cinema. A estreia ocorreu em $1^{\circ}$ de dezembro ainda de 1938. Foi objeto de louvação e imenso êxito de público; conseguiam-se bilhetes somente para muitos dias depois, e falava-se de pessoas que, não satisfeitas com uma única vez, voltavam outras mais para assistir à película ${ }^{8}$.

Em agosto do ano seguinte, Stálin assinaria com Hitler o infame tratado de não agressão por dez anos, e todos os filmes

8 lu. V. Krivochéiev; R. A. Sokolov, "Periodítcheskaia petchat' o fil'me 'Aleksandr Niévski'. Tchast I" ("A imprensa periódica acerca do filme 'Aleksandr Niévski'. 1938-1939. Parte I"), in Noviéichaia istóriia Rossii (História Moderna da Rússia), n. 1, 2012, pp. 178-192 (tchast' II/ parte II em: n. 2, 2012, pp. 114-35). 
em que russos guerreassem com alemães foram tirados de cartaz ${ }^{9}$.

Mas por que Aleksandr Iaroslávovitch ("filho de Iaroslavl"), nascido em 30 de maio de 1220 e tornado príncipe de Nóvgorod em 1236, ficou conhecido como Aleksandr Niévski (“do Nevá”)?

Segundo a tradição, aos 15 dias de julho de 1240, na foz do Rio Nevá (onde, em 1703, se ergueria a cidade de São Peterburgo, por Pedro, o Grande), uma pequena tropa, comandada por Aleksandr, enfrentou suecos ali acampados. Historiadores afirmam que tal combate não passa de conto da carochinha; outros até o admitem como realmente acontecido, mas negam-lhe a alegada importância; para eles, fora apenas mais um episódio trivial, entre muitos, e com poucos participantes, da duradoura rivalidade do principado de Nóvgorod com a Suécia por zonas de influência e acesso a rotas comerciais, marcada por sucessivas quebras de tratados de paz, pelo que, presumivelmente, ela não aparece em nenhuma fonte do país escandinavo.

Mas, enfim, a tal "batalha do Nevá" entrou para a história como um acontecimento grandioso, no qual Aleksandr, apesar da pouca idade, teria revelado excepcional talento militar, e haveria sido por ela que o apodo "Niévski" lhe obliterou o patronímico (estudiosos discordantes da historiografia oficial, porém, creditam-no meramente a

9 Também conhecido como "pacto Mólotov-Ribbentrop", foi assinado em 23 de agosto de 1939, em Moscou, e estipulava que as partes não atacariam uma a outra durante dez anos. Permitiu que Hitler invadisse a Polônia, sem temer reação soviética, e continha um protocolo secreto que estabelecia a divisão daquele país e do resto da Europa oriental em esferas de interesse soviético e alemão. prováveis domínios do príncipe na região do referido rio). E quando tal haveria ocorrido também está longe de consenso: se logo após a tal pugna, se 40 anos após a morte dele (1263) ou se somente já no século $\mathrm{XIV}^{10}$.

O trecho musical inicial é uma toada de nénia pelas vidas russas tombadas em combates renhidos contra os mongóis. A Rus (nome antigo da Rússia) fora invadida pelas hordas de Batý, neto de Gêngis-Khan; a primeira vaga, em 1237, destruíra todo o principado do Noroeste, e a segunda, em 1239, devastara o Sul, a Rus kievana. Ardera a maior parte das cidades e os seus habitantes foram mortos ou levados para o cativeiro. Permaneceram intactas apenas Nóvgorod e Pskov.

A tristeza ambiente bafeja, com a brisa, os despojos e ossos espalhados pelo campo, e verte-se com a trilha sonora no vasto panorama do Lago Plechtchéevo e do horizonte, espécie de expressão espacial da imensa dor de um povo. A atmosfera de pesar, porém, desfaz-se, no dia ensolarado, com o epinício da batalha do Nevá, a música de Sergei Prokófiev e os versos do poeta Vladímir Lugovskoi ${ }^{11}$.

“ПЕСНь оБ АЛЕКСАНДРЕ НевСКОм

А и было дело на Неве-реке, На Неве-реке, на большой воде. Там рубили мы злое воинство, Злое воинство, войско шведское.

10 Eisenstein abraçou a primeira versão: no primeiro diálogo do filme, um forasteiro pergunta ao príncipe: "Ty bil chviédov?" ("Foste tu que bateste os suecos?").

11 A melhor execução da cantata está em: https://www. youtube.com/watch? $v=c 7 R s 00 U H-C E \& t=396 s$. 
Ух, как бились мы, как рубились мы!

Ух, рубили корабли по досточкам.

Нашу кровь-руду не жалели мы

За великую землю русскую.

Где прошёл топор, была улица,

Где летело копьё - переулочек.

Положили мы шведов, немчинов,

Как ковыль-траву на сухой земле."

\section{(“CÂntico de Aleksandr Niévski}

Foi o caso no Rio Nevá,

No Rio Nevá, na cheia da Primavera.

Ali destruímos uma hoste feroz,

Uma hoste feroz, o exército sueco.

Ah, como nos batemos, como terçamos armas! Ah, despedaçamos os seus barcos.

O nosso sangue quente não poupamos nós Pela grande terra russa.

Por onde passou o machado, ficou uma estrada,

Por onde voou a lança, uma trilha.

Nós ceifamos os suecos e alemães

Como capim sobre a terra seca.")

O canto interrompe-se com a chegada de um cortejo de prisioneiros (precisamente quando, no canto direito da tela, surge, pela primeira vez, a figura alta do príncipe, que puxa rede com pescadores). Impossível não notar o contraste, primeiro, da beleza da língua russa e do cântico com a algaravia gutural dos ocupantes e, segundo, do estrangeiro baixo, gordo e de fala melíflua, ridiculamente parecido ao Mickey Mouse, com o alto, altivo e bem-posto Niévski ${ }^{12}$.

Quando se vai o forasteiro, Aleksandr diz a um velho camarada de armas que não se poderia lutar com dois fortes inimigos simultaneamente: havia também uma ameaça do Ocidente. O papa Gregório IX, em conti- nuidade à missão encetada pelo antecessor, Honório III, emitira já três bulas (1232, 1233 e 1237) de conclamação a que se levasse o catolicismo para o Leste da Europa ${ }^{13}$. Desde havia muito, terras às margens do Mar Báltico estavam ocupadas por uma ordem de cavaleiros guerreiros, a qual daria lugar, mais tarde, à Ordem Teutônica, e o território das atuais Letônia e Estônia pertencia à Ordem Livônica; esta e aquela uniram-se em 1237, com intermediação da cúria romana,

12 O forasteiro faz uma oferta de emprego ("Nam voievódy nujný"/“Precisamos de chefes militares") a Niévski, e este não a aceita. Bem, isso foi um golpe de Eisenstein à verdade histórica. Os príncipes russos deviam obediência ao kan mongol, que Ihes concedia um iarlyk (insígnia) para este ou aquele principado; o pai de Aleksandr, laroslavl, foi o primeiro a ir a Kara-Karum (Mongólia), onde, crê-se, foi envenenado; em 1248, para ali dirigiram-se Aleksandr e Andriéi, seu irmão menor; este recebe os direitos de "grande príncipe" e segue para Vladímir, e aquele é declarado "príncipe de Kíev e de toda a Rússia". Aleksandr, porém, não foi para Kíev, que estava arruinada (em 1169, pelo exército de Andriéi Bolíubskii, príncipe de Súzdal' e Vladímir, e em 1240, pelos mongóis), mas para Nóvgorod.

Em 1252, Aleksandr é convocado a Sarai (cidade próxima ao estuário do Volga), onde ficava o quartel-general de Baty, que lhe concede o principado de Vladímir, contrariando o ato do kan; Aleksandr toma a cidade, acompanhado de grande destacamento mongol, e obriga Andriéi a fugir e refugiar-se na Suécia. Ele envidou muitos esforços para que as terras do Noroeste, então território russo livre, fossem incorporadas aos domínios dos asiáticos. Em 1256, esmagou com crueldade uma revolta de Nóvgorod contra a inventariação e recenseamento, promovida pelos ocupantes. Morreu em 14 de novembro de 1263, em Gorodiéts, lugarejo do Volga, no caminho de volta da sua quarta ida a Sarai. Foi enterrado em Vladímir e os seus restos mortais foram transferidos para Petersburgo por Pedro, o Grande, em 1724.

Claro está, não se poderia mostrar esse lado colaboracionista da personagem, visto por muitos historiadores como expressão de um grande talento diplomático. Eisenstein executava o projeto, mas o produto pertenceria ao estúdio; este, com o dinheiro para as despesas, dera-Ihe instruções bem claras do que não poderia ser mostrado e impingira-lhe Dmítrii Vassíliev, diretor afinado com as diretrizes do regime, como assistente.

13 Para os generais romanos de batina, os russos (Rutheni), embora cristãos desde o ano 999 da nossa era, pela adoção da fé ortodoxa de Bizâncio, eram inimigos (inimici) a quem se deveria tratar sem piedade. 
e procuraram aproveitar-se da calamitosa situação da Rus.

Afirmam alguns historiadores que aquele grupo sueco, derrotado na tal batalha do Nevá, fora um peão dessa campanha e que a ele era para se haver juntado uma milícia das duas citadas ordens, a qual acabara por atrasar-se (a velocidade de avanço de um grupo armado grande, por terra, então, era de, no máximo, 20 quilômetros por dia). $\mathrm{O}$ fato é que, algum tempo depois, um exército dos novos cruzados tomou Izvorsk, fortaleza próxima a Pskov e, em seguida, a própria cidade; os cavaleiros germânicos iniciaram, então, hostilidades contra Nóvgorod; ergueram uma fortificação de madeira às margens do Rio Kaporka, sobre uma grande elevação de terreno, e ela permitiu-lhes interceptar os barcos de mercadores que se dirigiam ao golfo da Finlândia pelo Rio Nevá. A situação de Nóvgorod era desesperadora, e a sua plutocracia, os boiardos, foi a Pereslavl-Zaliésski pedir ajuda a Aleksandr Iaroslávovitch ${ }^{14}$.

Outro objeto de discordância dos historiadores contemporâneos é quem representava, na perspectiva histórica, a maior ameaça à Rus naquele passo: o Oriente ou o Ocidente? Para alguns, este haveria sido um poderoso aliado contra aquele e uma escolha mais apropriada, porquanto, afinal era cristão. Para outros, embora houvessem

14 As cidades russas eram governadas por uma assembleia de boiardos (a aristocracia local), chamada vietcha. Ela constituía o círculo mais próximo do príncipe (que era apenas o primeiro entre iguais), controlava- Ihe as ações, impunha-lhe as suas decisões e podia imiscuir-se até na vida privada dele, como, por exemplo, escolher-lhe com quem casar-se e onde morar. Ela expulsara Aleksandr laroslávovitch de Nóvgorod, acredita-se, por inveja do prestígio por ele adquirido com as suas campanhas militares. chegado e promovido enorme devastação e, de tempos em tempos, realizassem expedições de saqueio e derramassem sangue, os mongóis iam-se com o butim, eram tolerantes em matéria religiosa e deixavam o governo das terras e cidades aos príncipes, exigindo deles apenas o pagamento de tributos e submissão ao kan; uma sublevação contra os poderosíssimos invasores, ademais, haveria colocado sob risco a sobrevivência da nação, dividida em principados rivais; ainda segundo tal opinião, os ocidentais, por sua vez, visavam à conquista de territórios e aniquilaram todos os nobres da Estônia e da Látvia, escravizando os seus povos; sendo, ademais, fanáticos religiosos, que não admitiam outros modos de pensar e viver, exterminaram uma população prussiana do Báltico e as tribos eslavas dos líutitchis e bódritchis e encaravam os russos e os fino-úgricos como selvagens e bárbaros, dignos de continuarem vivos somente se catequizados e cativos ${ }^{15}$.

Está de acordo com tal linha de pensamento a resposta de Niévski ao velho sedento de vingança contra os mongóis. Como estes não cobiçaram as terras de Nóvgorod e Pskov, que permaneciam territórios livres, o príncipe (não esqueçamos, sempre o Aleksandr de Eisenstein) considera segura a retaguarda e afirma a urgência de fazer frente, primeiro, aos inimigos ocidentais. É quando

15 Para mais pormenores, ver: A. N. Ujankov, "Miéjdu dvukh zol (Istorítcheskii výbor Aleksandra Niévskovo)" ("Entre dois males: a escolha histórica de Aleksandr Niévski"), in Rossia XXI, n. 2, 1999, pp. 102-43; S. V. Rybakov, "Strateguítcheskii výbor Aleksandra Niévskovo" ("A escolha estratégica de Aleksandr Niévski"), in Mir Evrázii (O mundo da Eurásia), n. 4 (23), 2013, pp. 50-4. Para Pavlienko e Eisenstein a questão já estava resolvida: os nazistas representavam o Ocidente e, portanto, era contra os cavaleiros cruzados que os russos de Niévski deveriam ir. 
o coro entoa a parte final do epinício da batalha do Nevá. A recordação da passada glória constitui um juramento de defender a pátria e uma ameaça a quem ousar atacá-la; o tom solene reflete a consciência da ingente força coletiva dos russos:

“Не уступим мы землю русскую.

Кто придёт на Русь,

Будет насмерть бит.

Поднимайся, Русь, супротив врага;

Поднимись на бой,

Славный Новгород!”

("Não cederemos a terra russa.

Quem marchar sobre a Rus,

Será aniquilado.

Ergue-te, Rus, contra o inimigo;

Ergue-te para o combate,

Gloriosa Nóvgorod!").

Começa, então, a reunião de forças para a defesa da fronteira ocidental. Em contraposição ao silêncio das covas dos quadros iniciais, das zemliánki (abrigos cavados no solo) sai gente aos borbotões, ao som de sinos: é a Rus, que se ergue para a luta, em atendimento ao verso "Vstaváitie, líudi rússkiel" ("Levantai-vos, ó russos”) da cantata. Aleksandr, com a ajuda de tropas do irmão Andriéi, enviado de Vladímir pelo pai, Iaroslavl, toma Kapórie, a fortaleza do Rio Kaporka, e reabre a rota de comércio; em seguida, libera Pskov ${ }^{16}$ e avança por terras do inimigo, para rapina, mas os seus dois esquadrões dianteiros são

16 Pela rivalidade com Nóvgorod, os boiardos de Pskov haviam assinado um tratado de paz com a Ordem, que deixara nela dois administradores e 30 cavaleiros. Não deve ter sido difícil para Aleksandr laroslávovitch vencer tão pequena guarnição. aniquilados e ele recua até à margem oriental do Lago Tchudskóie, na fronteira atual da Rússia com a Estônia.

O lugar central, no roteiro de Pavlienko, pertencia à Batalha do Gelo e a ação concentrou-se nos eventos conducentes a ela, para exaltar a face mais adequada do príncipe Aleksandr ao decênio de 1930, em que a agressão nazista era já havida como certa pelo governo soviético: a de defensor da pátria e guerreiro valoroso. Antes, porém, deveremos responder a uma pergunta: como pôde um senhor feudal, príncipe (já se vê, um parasita que vive às custas do povo) e santo da Igreja Ortodoxa (um produto da fábrica de ópio da religião, portanto) tornar-se herói de um filme patriótico em um país autoproclamado "comunista, ateu e de trabalhadores"?

\section{$* * *$}

A jovem república passara às suas urgentes tarefas: estabelecimento do poder dos sovietes, combate ao banditismo, aumento da produção de alimentos, abastecimento das cidades, edificação duma base industrial, erradicação do analfabetismo, coletivização da agricultura, etc. A dura realidade, em que tudo relacionado com a Rússia dos tsares e de antes era considerado abominável, fez os estudos do passado medieval serem vistos como algo fora de moda e não atraírem estudantes (aliás, as universidades até fecharam a cátedra de História); interessavam apenas a história do movimento revolucionário e a do Partido Comunista.

Com o triunfo de Stálin na hierarquia de poder (1927), a eliminação física da velha guarda bolchevique, o malogro da ideia da revolução permanente, com o exílio força- 
do de Trótski, e o estabelecimento de um regime brutal, que se impunha pelo terror, os valores comunistas e internacionalistas foram sendo postos de lado e substituídos pelo patriotismo mais tradicional. Esse nacionalismo soviético não tinha nada em comum com, por exemplo, o de Maiakóvski em "O passaporte soviético"17 e era, essencialmente, a lealdade política ao Estado (ou, se quisermos, a Stálin) e a disposição a defender o país dos inimigos externos. Que os havia, e muitos, é verdade.

O mundo capitalista ocidental proscrevera a União Soviética, contrariado com a derrota do exército branco, a que ajudara com tropas na guerra civil (1919-1921), e o comunismo fora declarado a maior ameaça à civilização cristã. A atitude hostil em relação à "sexta parte da superfície de terra do globo" atingiu o máximo grau com a ascensão do nazismo no país mais rico e poderoso da Europa Ocidental. A crença na superioridade ariana propugnava que as pessoas "racialmente inferiores", como os judeus e os ciganos, a par dos eslavos, deveriam ser eliminadas; mais, a cobiça por matérias-primas, combustíveis e fontes de suprimento gerara planos de expansão para o Leste europeu. Por qual meio? O único possível: a força militar. De forma que para os espiões e os diplomatas soviéticos, lotados em território germânico, o envio de tropas, apoiadas por tanques com a cruz suástica,

17 No poema, de 1929, fala-se da vária atitude dos guarda-fronteiras estrangeiros diante dos passaportes dos viajantes. O soviético parece-lhes uma bomba e mete-Ihes medo. O poeta escreve: "Invejai, eu sou um cidadão da União Soviética!", orgulhoso do seu imenso e vitorioso país, que fazia até um militar tremer diante do livreto encarnado e, achava ele, inaugurara uma nova era nos rumos da humanidade. em direção às férteis planícies da Ucrânia e aos campos petrolíferos do Mar Cáspio, era mera questão de tempo. A URSS, ademais, tinha só vizinhos hostis nas suas fronteiras ocidentais - Maiakóvski novamente, com "Ao camarada Nette, navio e pessoa"! ${ }^{18}$ E, no Oriente, florescia o militarismo nipônico.

E que faz uma nação, em semelhante situação, quando sente uma ameaça do exterior? Procura, por todos os meios, convencer os seus cidadãos de que eles têm algo que devem defender e de que devem orgulhar-se. A parcela majoritária da população russa experimentara significativa melhora das suas condições de vida; fizera-se grande esforço para a instrução das massas, principalmente dos jovens, com a construção de escolas e a criação de cursos técnicos e superiores e de uma rede nacional de bibliotecas, cinemas, teatros, museus e espaços para atividades culturais, pois somente gente instruída poderia operar máquinas e aperfeiçoá-las, elaborar planos para obras de infraestrutura e promover o desenvolvimento científico e econômico do país; simultaneamente, a propaganda inculcava nas pessoas a crença no valor do seu trabalho para uma vida melhor numa sociedade mais justa, e orgulho pela sua terra.

Muito do espírito da época, marcado pelo romantismo da participação em grandes ações coletivas, exigidoras de abnegação e entusiasmo, chegara à juventude pela

18 No dia 5 de fevereiro de 1926, em trem que seguia de Moscou para Riga, em tiroteio com mercenários, já em território da Letônia, defendendo a mala diplomática soviética, morreu o agente Teodor Nette, amigo de Maiakóvski, e foi gravemente ferido o seu companheiro, Johan Machmastal. O fato causou comoção nacional e motivou um filme (Sumka dipkuriera/A mala do correio diplomático, 1927) de Aleksandr Dovjenko. 
literatura, por livros como A torrente de ferro (Jeliéznyi potok, 1924), de Aleksandr Serafimóvitch (1863-1949), e Como se temperou o aço (Kak zakaliálas' stal', 1932), de Nikolai Ostróvskii (1904-1936). Outro meio importante de educação ideológica foi a canção popular (naródnaia piésnia), cujos primeiros modelos foram "A Marselhesa" e hinos revolucionários, como a "Internacional", "Varchavianka" e "Bandiera Rossa”, entre outros; obra de compositores profissionais (como Dmítrii Chostakóvitch) e amadores, com estrofes e ritmo de marcha e, frequentemente, palavras de ordem no refrão, a canção popular expressava as ideias e sentimentos gerais de forma simples e clara: cantava-se nos lares e, principalmente, em demonstrações de rua, comícios e outros grandes eventos sociais ${ }^{19}$.

Para o fomento do patriotismo, outro meio eficaz revelou-se a memória histórica, com a evocação de um passado que contivesse lições de vida e exemplos heroicos para serem mostrados principalmente às jovens gerações; utilizou-se a história como catalisadora de tal processo: em 1934, a disciplina voltara a lecionar-se na escola e na universidade, e na imprensa começaram a publicar-se matérias com juízos positivos acerca de acontecimen-

19 Como ilustração serve a "Marcha da moçada alegre" ("March vessiólykh rebiat", 1934), de Issaak Dunaiévskii (1900-1955), acerca da importância do canto e do riso para a vida humana. Eis as suas três últimas estrofes (disponível em: https://www.youtube.com/ watch?v=3Vyt1w5IcTQ): "Nós podemos cantar e rir como crianças,/ Em meio à luta e ao trabalho duro,/ Pois viemos ao mundo dum jeito,/ Que não nos entregamos nenhures e nunca.// $\mathrm{E}$, se o inimigo a nossa viva alegria/ De novo quiser em duro combate,/ Nós, então, entoaremos um canto de guerra/ E defenderemos com o peito a Pátria.// Cantar ajuda-nos a construir e viver,/ Ela leva-nos em asas à vitória./ E quem for pela vida com uma canção,/ Nunca e nenhures se verá perdido". tos e pessoas do passado ${ }^{20}$. E o cinema, se estivera, até então, distante da política, agora põe-se a serviço da ideologia. De 1933 a 1940, produziram-se 308 filmes, dos quais 61 acerca da revolução e da guerra civil, em geral sobre pessoas de comportamento heroico e não apenas militares, as quais, muitas vezes, tinham de haver-se com um inimigo externo ${ }^{21}$. Assim, veio naturalmente o Aleksandr Niévski, a que se seguiram, dos estúdios, grandes produções como Suvórov (1940) e Kutúzov (1943), entre outras.

\section{$* * *$}

A Batalha do Gelo, praticamente esquecida até o decênio de 1930, só deixou de

20 Mais pormenores em: A. L. Guriánov, "Rol' soviétskovo kinematógrafa v vospi-tánii soviétskoi molodióji v predvoiénnye gódy" ("O papel do cinematógrafo soviético na educação da sociedade soviética nos anos do pré-guerra"), in Aktuál'nye probliémy gumanitárnykh $i$ estiéstvennykh nauk (Problemas atuais de ciências humanas e naturais), n. 12, 2010, pp. 76-80.

21 Exemplo cabal desse revisionismo são dois trechos de discursos de Stálin, o primeiro de 1938, em cerimônia não oficial: "Os imperadores russos fizeram muitas coisas más. Eles espoliaram o povo e escravizaram-no. Eles travaram guerras e apoderaram-se de territórios, em nome do interesse dos senhores de terras. Mas eles fizeram uma coisa boa: eles consolidaram um Estado imenso, que vai até à Kamtchatka. Nós herdamos esse Estado. E, pela primeira vez, nós, bolcheviques, consolidamos e fortalecemos o Estado como um Estado uno e independente, não no interesse de senhores de terras e capitalistas, mas em benefício dos trabalhadores, de todos os povos, que constituem tal Estado". E em 7 de novembro de 1941, na famosa parada das tropas na Praça Vermelha: "[...] Que vos inspire, nesta guerra, a figura corajosa dos nossos grandes antepassados: Aleksandr Niévski, Dmítrii Donskoi, Kuzmá Mínin, Aleksandr Suvórov, Mikhail Kutúzov!". Citamos por: S. P. Bytchkov, "Aleksandr Niévski: istotrítcheskii prototip i ekránnyi óbraz" ("Aleksandr Niévski: o protótipo histórico e a figura da tela"), in Viéstnik Ómskovo universitieta (Anais da Universidade de Omsk), n. 1, 2004, pp. 60-3. Quer dizer, então, que os aristocratas e senhores de terras e de escravos de antigamente não eram tão maus? Cf. a conhecida frase de Lenin: "A Rússia tsarista era uma prisão de povos". 
ser tratada apenas de passagem, nos manuais de história e cursos universitários, com o perigo externo. Ela ocorreu no dia 11 de abril de 1242 (pelo calendário gregoriano) e aparece em quatro fontes russas e em uma alemã (a crônica rimada da Ordem Livônica, de uns 40 anos após ela), na qual se reconhece a derrota (mais ou menos em termos como "os nossos irmãos-cavaleiros bateram-se valorosamente, mas foram vencidos" $)^{22}$. Após ela, houve pelo menos mais um combate, ainda maior, numa sequência de hostilidades, estendidas pelos séculos subsequentes, por disputa de territórios, influência política e rotas de comércio. A ideia consagrada dela é obra de Eisenstein e, segundo muitos estudiosos, não corresponde à verdade histórica. Os estudiosos creem muito menor o número de participantes nela, com, no máximo, 20 a 30 cavaleiros armados para cada lado, e consideram a possibilidade de a vitória haver saído aos russos menos por alguma estratégia de combate do que por alguma circunstância do momento e do lugar; para além de excluírem totalmente o banho mortal dos cruzados: a água, em abril, quando a camada de gelo de rios e lagos é já fina, não haveria escolhido engolir membros só de uma parte, quando a contrária portava armaduras igualmente pesadas. Ademais, na crônica da Ordem Livônica, fala-se em "erva sob as patas dos cavalos".

Iniciadas em 1931, as buscas pelo local do combate prosseguem até hoje. Uma ex-

22 Nenhuma tentativa, portanto, de creditar a vitória do oponente a fatores climáticos, lição aos hipócritas que sustentam que os franceses de Napoleão (1812) e os nazistas não foram derrotados pelos bravos russos, mas pelo general-inverno. pedição entre 1956-1962, organizada pela Academia das Ciências da URSS, composta de historiadores, militares e geólogos, com trabalhos de mergulho e aerofotogrametria, percorreu os arredores do Lago Tchudskóie e estabeleceu que a tal Pedra do Corvo, onde o príncipe Niévski e os seus camaradas de armas haveriam esperado pelo inimigo, se encontra submersa, a noroeste duma certa Ilha do Corvo ${ }^{23}$.

A anedota do coelho perseguido por uma raposa, que fica entalada entre os troncos de duas bétulas, por onde aquele se metera, serve a Niévski de inspiração para atrair o adversário para aquele outeiro: os cavaleiros armados, escol da força inimiga, romperiam facilmente, com a sua formação em cunha, a primeira defesa, constituída por lanceiros, mas seriam detidos por uma corrente de trenós atados um ao outro e pelo clivo do Corvo e, cercados pela infantaria e sem espaço para manobrarem os cavalos, seriam presa fácil de um ataque pelos flancos.

Eisenstein teve a colaboração de um general de cavalaria, Liev Dovátor, encarregado das cenas de massa de cavaleiros - oficiais e praças do seu regimento, dos quais um tenente foi o dublê de Tcherkássov. Por incrível que possa parecer, tudo foi feito não sobre um lago congelado, nem em campo aberto, mas em pleno verão, num grande terreno plano próximo do estúdio Mosfilm, em Moscou. Coberta

23 Para mais pormenores ver: lu. V. Krivochéiev; R. A. Sokolov, "Ledóvoie pobóichtche 1242 goda: issliédovateli i issliédovaniia" ("A Batalha do Gelo de 1242: pesquisadores e pesquisas"), in Studia Slavica et Balcanica Petropolitana, n. 1, jan.-jun./2014, pp. 3-10. Este, como todos os outros artigos russos citados, encontram-se em: elibrary.ru. 


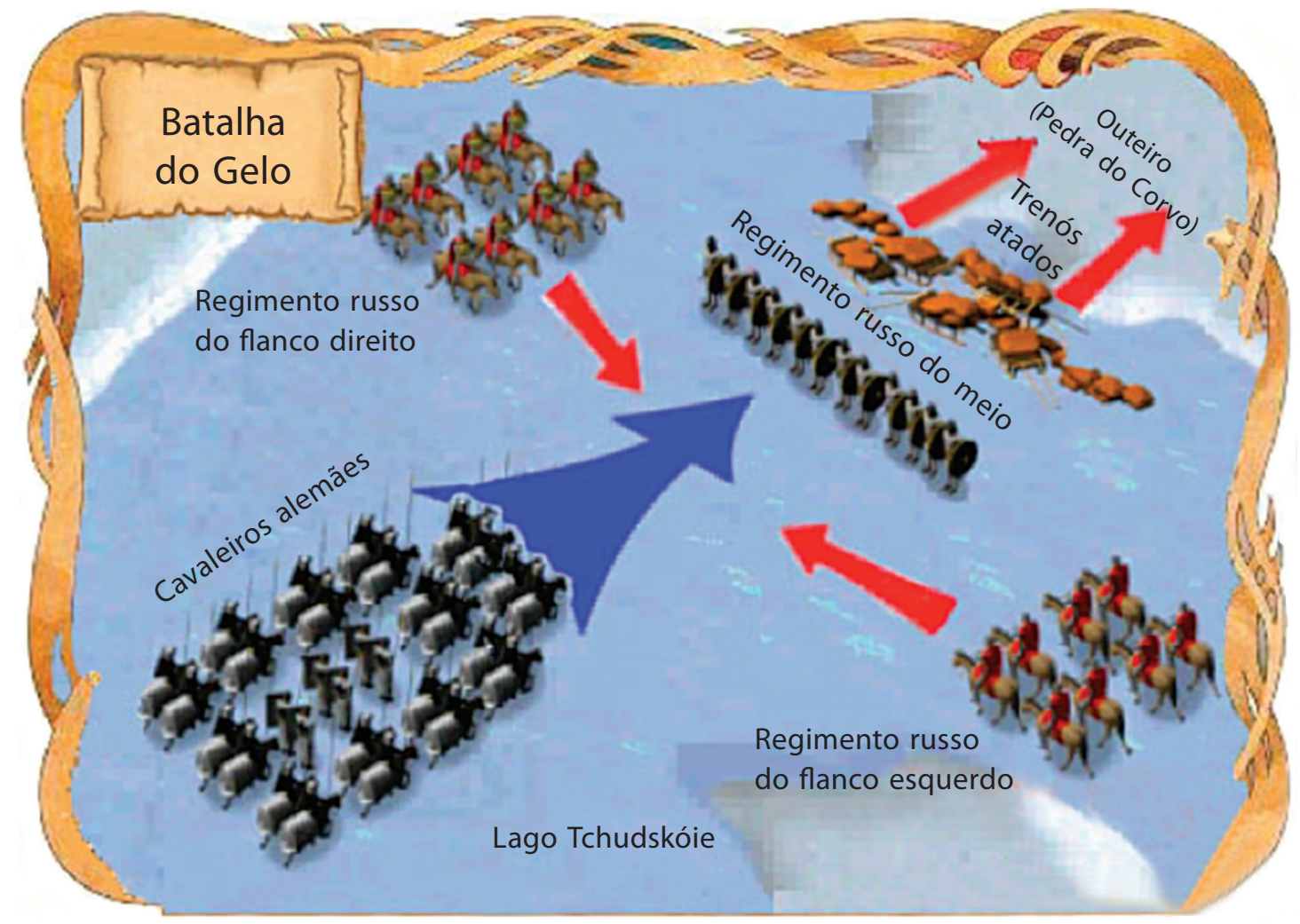

Disposição das forças sobre o lago gelado: a tática de Niévski

toda a área com serragem, naftalina e sal, sobre ela deitou-se giz diluído em água, vestiram-se ramos de árvores com algodão e esses elementos produziram a impressão de estar-se no rijo inverno russo. Foi numa pequena lagoa das proximidades que os teutônicos (na verdade, nadadores de clubes moscovitas) afundaram, não tendo conseguido agarrar-se aos blocos de gelo, grossas peças de madeira compensada, pintadas de branco.

O que se vê, com a música de Prokófiev ao fundo, é uma expressão da mais alta arte. Um eco daqueles tempos fez-se ouvir pelo elenco, figurantes e equipe do estúdio: conta Tcherkássov, em livro de memórias, que descansavam todos, certa vez, sentados à beira do fictício Lago Tchudskóie, quando trouxe alguém um exemplar do jornal Pravda do dia, com a notícia de que o Exército Vermelho repelira, dias antes, uma incursão japonesa em território soviético, na região do Lago Khassan, perto da fronteira com a atual Coreia do Norte (29 de julho a 9 de agosto de 1938); em alguns minutos, aquilo, lido e relido aqui e acolá, comoveu aquelas centenas de pessoas e sugeriu-lhes que também elas tinham de "fazer a sua parte", e a filmagem prosseguiu com entusiasmo.

Aleksandr Niévski não é tanto acerca da personagem, quanto da época da sua realização. O lago é a Europa Ocidental e os russos, que, da sua posição, observam a aproximação dos cavaleiros cruzados, representam a União Soviética atenta à ameaça nazista. Pela capacidade de transportar o espectador para o longínquo passado, 
pela memorável música, pelo talento do realizador e pelo desempenho dos atores, o filme, que cumpria, como todos os seus congêneres soviéticos do decênio de 1930, uma determinada tarefa política, entrou para a história do cinema.

Por fim, três coisas. Teria a justiça sumária, aplicada aos traidores de Pskov, sido uma alusão aos processos de Moscou, em que se julgavam os ditos "traidores do Partido e do povo"?

Não terá sido uma concessão às "altas instâncias ideológicas” a inclusão massiva e entusiasmada do povo (armado com ferramentas agrícolas!) na resistência ao invasor externo, quando, no Medievo, ações bélicas cabiam, fundamentalmente, aos nobres e às suas milícias de guerreiros profissionais?

E perdoemos, do mais bom grado, a Eisenstein e auxiliares a seguinte trapalhada: numa cena, pouco antes da batalha do gelo, Tcherkássov está com um elmo que mais parece um capacete de motociclista; na seguinte, aparece com outro e, logo depois, de novo com o primeiro... 